\title{
Cognitive Development for Preschooler 4-5 Year Olds by Using PowerPoint Audio-Visual Media on ECE Students
}

\section{Ni Dewi Eka Suwaryaningrat}

Department of Teacher Education for Early Childhood Education,

Faculty of Science Education, Universitas Negeri Manado, 95618, North Sulawesi, Indonesia Corresponding Author: nidewiekha@unima.ac.id

\section{ARTICLE INFO}

Publication Info:

Research Article

How to cite:

Suwaryaningrat, N. D. E. (2020).

Cognitive Development for

Preschooler 4-5 Year Olds by

Using PowerPoint Audio-Visual

Media on ECE Students. Society,

$8(2), 772-782$.

DOI: $10.33019 /$ society.v8i2.276

Copyright $($ C 2020. Owned by Author(s), published by Society

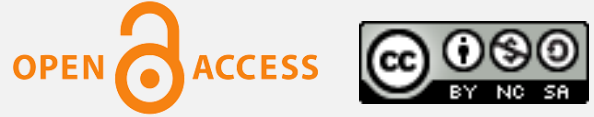

\section{ABSTRACT}

This study aims to determine whether using PowerPoint audio-visual media can improve children's cognitive development in ECE (Early Childhood Education) in North Tomohon Sub-District, North Sulawesi Province, Indonesia. The research method used was collaborative Classroom Action Research (CAR) conducted in ECE in North Tomohon SubDistrict, and it was found that 1) Before using the PowerPoint audio-visual media, ECE in North Tomohon Sub-District still had difficulty doing the assigned tasks and answering teachers' questions because the children cognitive was not stimulated well; 2) The use of PowerPoint audio-visual media can improve the child's cognitive aspects because the learning activities were designed in an attractive, fun and not boring way. Through the use of PowerPoint audio-visual learning media, children's cognitive can be stimulated well.

This is an open-access article.

License: Attribution-

NonCommercial-ShareAlike

(CC BY-NC-SA)

Received: December 8, 2020;

Accepted: December 28, 2020;

Published: December 31, 2020;

Keywords: Cognitive; Early Childhood Education; PowerPoint

Copyright (C) 2020. Owned by Author(s), published by Society. This is an open-access article under the CC-BY-NC-SA license. 


\section{Introduction}

Early Childhood Education (ECE) is a coaching effort carried out by providing educational stimuli to develop children's potential to function as intelligent and beneficial human beings for the nation. ECE can be organized through the formal or informal pathway. This is based on the Law of the Republic of Indonesia No. 20/2003, Article 28, Paragraph 3, which mentioned early childhood education on formal education pathways in Kindergarten, Raudathul Athfal (RA) other equivalent forms (Republik Indonesia, 2003). Thus, kindergarten is early childhood education through formal education pathways, while the informal pathways are Play Group and Childcare. Children at the kindergarten education level are at the age of 4-5 years. The child begins to be sensitive or experiencing a sensitive period to receive all their potential development efforts. Interaction through objects and other people is necessary for children to develop all aspects of their development. The developmental aspects in question are religious and moral values, motor physique (rough and smooth motor), cognitive, language, emotional, social, and art. Cognitive development is one of the important aspects of development to develop children's thinking abilities. So that both parents and teachers need to know the stages of child development, if there are obstacles in previous developments, further developments will encounter obstacles (Sudarna, 2014).

Cognitive of children aged 4-5 years in ECE in North Tomohon Sub-District is still not developed properly. There was a problem when giving an assignment in sorting objects from small to large or arranging symbols number 1-10, where there were children who had been able to do well, and there were children who had not been able to do as expected. This is because the learning model used by teachers is less attractive to students. In teaching, teachers prefer the learning model of lectures to the other models. The teaching-learning process tends to be directed at the flow of information from teacher to student (teacher center learning), which means the use of lecture methods is very dominant in the learning process. The low quality of education can be interpreted as the lack of success of a learning process. The causative factors can come from students, teachers, or learning media used.

Children's cognitive development in ECE in North Tomohon Sub-District in learning has not been appropriately achieved because they are tired of teachers' media. By using only visual media and lecture methods, some children already understand the themes taught. In contrast, some other children don't because the learning media is less attractive so that the children cognitive has not developed properly. No more than $50 \%$ of children show well-developed cognitive development. Low cognitive development affects children's learning outcomes which are only $35 \%$ complete so that $65 \%$ of children have not completed their learning. This can be seen from the children's learning outcomes at the time of giving the assignment.

Therefore, a new learning method is needed to improve the quality of the learning process. The chosen method is learning through PowerPoint audio-visual media to improve children aged 4-5 years. By using this learning medium, children's cognitive abilities can be improved because, in the learning process, there will be included media that has elements of sound and images and moving images or videos to enhance the child's cognitive development.

In ECE in North Tomohon Sub-District, the learning process has never been carried out through PowerPoint audio-visual media to improve children's cognitive development at the age of 4-5 years to improve children's learning outcomes. 


\section{Literature Review}

2.1. Concepts of Cognitive Development

\subsubsection{Definition of Cognitive}

Education and learning in children should be carried out to provide basic concepts that have meaning for the child through real experience and enable them to show high activity and curiosity. In the age range of 0-8 years, the child experiences a golden age, which is when the child begins to be sensitive to receive various kinds of stimuli. It is also the first period of laying the basic foundation for developing the religious, moral, motor, cognitive, language, emotional, social, and art. So it must be prepared and fostered early to achieve optimal development (Sudarna, 2014).

\subsubsection{Phases of Cognitive Development in Early Childhood}

Development is a cumulative process. This means that previous developments will become the basis for further development so that both parents and teachers need to know the stages of child development. If there are obstacles in previous development, then the further development will encounter obstacles. Piaget in Sudarna divides cognitive development into four phases, namely the sensorimotor phase, preoperative phase, concrete operation phase, and formal operation phase (Sudarna, 2014).

\subsection{Early Childhood}

\subsubsection{Definition of Early Childhood}

According to Sugiyono (2013), early childhood is an individual figure who is undergoing a rapid and fundamental development process for later life.

\subsubsection{Characteristic of Cognitive Development for Preschooler 4-5 Year Olds}

The cognitive development for preschooler 4-5 years old include:

a. Able to know the function of objects correctly,

b. Able to group objects by shape, color, size, and function simply,

c. Participate in reading activities by filling in empty words or sentences.

\subsection{Audio-Visual Media}

\subsubsection{Definition of Audio-Visual Media}

Audio-visual media is a type of learning media that can be used in the learning process. "Media" is derived from Latin and is a plural form of the word "medium," which means "intermediary or introduction". Thus, media is a vehicle for transmitting learning information or message. According to Sadiman, Media is a learning source, so media can be broadly defined as humans, objects, or events that allow students to acquire knowledge and skills (Sadiman, 2010).

\subsection{PowerPoint}

\subsubsection{Definition of PowerPoint}

Microsoft PowerPoint is software that helps compose an effective, professional, and easy presentation. PowerPoint media can help make an idea more interesting and clear its purpose when presented. PowerPoint media will help create slides, presentation outlines, electronic presentations, and displaying dynamic slides, including interesting clipart. All of that is easy to display on the computer monitor screen. Meanwhile, Sanaky pointed out that media PowerPoint is a presentation application program that is one of the applications under 
Microsoft Office computer programs and displays to the screen using LCD projector's help (Sanaky, 2011).

\section{Research Methodology}

\subsection{Research Design}

The research design used was collaborative Classroom Action Research (CAR). This research departs from ECE in North Tomohon Sub-District's problem where children's learning outcomes have not increased optimally. It is necessary to use this way to improve children's learning outcomes with cognitive development efforts through PowerPoint audio-visual media. This research used the Class Action Research (CAR) method from Kemmis and McTaggart consisting of stages: 1) Planning Stage, 2) Action Stage, 3) Observation Stage, 4) Reflection Stage (Iskandar \& Narsim, 2015).

\subsection{Research Procedures}

This research was conducted using a cycle. Each cycle uses four components of action: planning, execution or action, observation, and reflection in one interconnected spiral. Researchers continue into the next cycle if they have not met the target achievement of success indicators in this study. This cycle ends when it matches the indicators of success. To clarify the rotation in each cycle, a research design chart is used as follows:

Description:

Cycle

1) Planning

2) Implementation or action

3) Observation

4) Reflection

\subsection{Data Collection Instruments}

The data collection technique used in this research is observation techniques, namely the activity of directly observing the learning process. The tool used to collect data in this study was the observation instrument sheet. The following instruments are used to measure the level of achievement of children's interest in learning at ECE in North Tomohon Sub-district through learning strategies using PowerPoint audio-visual media.

\subsection{Data Analysis Technique}

Data analysis is a process of processing and interpreting data to show various information according to its function until it has a clear meaning and meaning following the purpose of research (Wina, 2011). Furthermore, to determine the effectiveness of a method used in this class action study, quantitative descriptive analysis was used. This study's quantitative data results from observations during the teaching and learning process using PowerPoint audiovisual media. The cognition of children aged 4-5 years will be improved through learning using PowerPoint audio-visual media, and the results of observations before and after action will be compared. Thus the results will be known.

To determine student's learning outcomes, calculations are performed using the following formula:

$$
\text { Formula: } \mathrm{LC}=\frac{T}{T t} \times 100 \%
$$


Description:

$\mathrm{LC}=$ Learning completion

$\mathrm{T}=$ Number of scores earned by students

$\mathrm{Tt}=$ Total number of scores

Each student is declared "mastery learning" if the correct answer is $75 \%$. Meanwhile, a class is considered "mastery learning" (classical completion) if there are $85 \%$ of students in a class have completed their learning (Trianto, 2011).

\section{Results and Discussion}

\subsection{Research Results}

This research aims to find out whether using audio-visual media PowerPoint can improve the cognitive abilities of children aged 4-5 years old. Because as we know that each child's cognitive development is different, and based on observations, the children in grade B1, on average are not able enough to understand the teacher's knowledge.

The first cycle of research was conducted in January 2020 with the theme "Work" and the weekly sub-theme "Doctor". This research uses four stages. The Description of Cycle I research is as follows:

\subsubsection{Cycle I}

1) Planning

At this stage, the researcher takes a syllabus to direct student learning according to the education curriculum unit, then compiles a Daily Learning Action Plan (DLAP) according to the theme that will be given.

2) Implementation or action

A daily learning Action plan (DLAP) that has been completed is then implemented by referring to the learning steps contained in DLAP. The learning steps are divided into three stages, namely:

\section{a. Initial Activities}

At this stage, the teacher/researcher enters the classroom and begins with greeting students, then continues with the morning worship and pray before learning and sing a song according to the theme that will be taught that day, then talking about the teaching activities carried out on the previous day by asking the children a question "who still remembers, what did we learn yesterday?" The children's answers can be the basis for researchers to determine the progress of children's knowledge in memorizing learning.

\section{b. Core Activities}

\section{Step I: Delivering today's learning activities}

In this step, the teacher tells students about today's learning: doctors and any medical equipment, using PowerPoint audio-visual media.

\section{Step II: Preparing students}

After explaining today's learning, researchers assisted the class teacher in arranging the student's seats in the form of a group. 


\section{Step III: Start learning activity}

After the researchers prepared the students, the researchers began the learning activity by displaying pictures in PowerPoint slides and videos about doctors' work and doctors' equipment.

\section{Step IV: Checking Children's understanding of the material presented}

After the researcher display images and videos about a doctor's work, researchers review a doctor's work and tools used by the doctor. In this activity, researchers give the child the opportunity to think according to their expectations, then the researcher asks questions about the material presented, such as "what are the duties of a doctor? what are the tools used by the doctor? Where does the doctor work?" Here the children begin to develop their cognitive by thinking about what they have heard and seen, then the children start guessing and begin to find answers according to their thoughts, and some children start telling stories about doctor's work according to what they have experienced in daily life.

\section{c. Closing}

At this stage, the teacher/researcher gives an evaluation in the form of an assessment sheet to know the extent of the child's cognitive development in understanding today's learning, and then the teacher gives appreciation and motivation to the child. In the end, the teacher invites the child to pray together after learning and then closes the learning process.

3)

\section{Observation}

At this stage, researchers collaborate with classroom teachers who act as observers. Where observations are carried out in common together with the learning process. The observation is conduct during the learning process, not at the end, and based on observations of the learning outcomes in cycle I and assessing the evaluation results. There is still a lack of the children's attention to the material presented using PowerPoint audio-visual media because they are still adjusting to using new learning media. Thus this class action research continues in the next cycle. The results of the implementation of the cycle I actions can be seen in the following table:

Table 1. Children's Learning Outcomes in Cycle I Learning

\begin{tabular}{|c|c|c|c|c|c|c|}
\hline \multirow{2}{*}{ No. } & Child & \multicolumn{3}{|c|}{ Assessment Aspect } & \multirow{2}{*}{ Score } \\
\cline { 4 - 6 } & Name & BB & MB & BSH & BSB & \\
\hline 1. & AX & & $\checkmark$ & & & 2 \\
\hline 2. & CJ & $\checkmark$ & & & & 1 \\
\hline 3. & CR & & $\checkmark$ & & & 2 \\
\hline 4. & ES & & & $\checkmark$ & & 3 \\
\hline 5. & FT & & & & $\checkmark$ & 4 \\
\hline 6. & GL & & & $\checkmark$ & & 3 \\
\hline 7. & HH & & $\checkmark$ & & & 2 \\
\hline 8. & JM & & & & $\checkmark$ & 4 \\
\hline 9. & JR & $\checkmark$ & & & & 1 \\
\hline 10. & KK & & & & $\checkmark$ & 4 \\
\hline 11. & LP & & $\checkmark$ & & & 2 \\
\hline 12. & MT & $\checkmark$ & & & & 1 \\
\hline 13. & QS & & & $\checkmark$ & & 3 \\
\hline
\end{tabular}




\begin{tabular}{|c|c|c|c|c|c|c|}
\hline \multirow{2}{*}{ No. } & Child & \multicolumn{3}{|c|}{ Assessment Aspect } & \multirow{2}{*}{ Score } \\
\cline { 3 - 6 } & Name & BB & MB & BSH & BSB & \\
\hline 14. & SM & & $\checkmark$ & & & 2 \\
\hline 15. & SB & & $\checkmark$ & & & 2 \\
\hline 16. & TR & $\checkmark$ & & & & 1 \\
\hline 17. & YK & & $\checkmark$ & & & 2 \\
\hline \multicolumn{7}{|c|}{ Total } \\
\hline
\end{tabular}

From the above results, it can be seen that the achievements are:

$=\frac{39}{68} \times 100 \%$

$=57,35 \%$

Based on the table above, it can be pointed out that there are 4 of 17 children who participated in the study who is Undeveloped (BB). It shows that the four children are still classified as having no cognitive development skills through PowerPoint audio-visual media. This means that the four children can't develop cognitive aspects, namely the lack of attention of the child during the learning, resulting in lack of ability to answer correctly during the assignment, for example in following directions, looking for traces, and the child is still confused to direct the ambulance car to the hospital using the dotted line. Meanwhile, seven children Start to Develop (MB), they are beginning to develop in the cognitive aspect where they can answer the task given by the teacher but not exactly as expected, for example, in arranging directions, the children are looking for traces and are not yet suitable from start to finish. However, the child began to try to steer the ambulance to the hospital despite using an irregular dotted line. And three children have Developed as Expected (BSH). Children have developed cognitive aspects in answering questions and completing tasks given by teachers but are still hesitant in answering questions. Three children are Very Well Developed (BSB). The three children have developed cognitive skills in completing the teacher's tasks and answering questions appropriately.

4) Reflection

Based on the observation stage, improving the cognitive abilities of children aged 4-5 years using PowerPoint audio-visual media at the stage of the cycle is still unsatisfactory or unsuccessful. This is because there are still many obstacles, such as children not completing the assigned task because the child is not familiar with using PowerPoint audio-visual media, which means that the child is adapting to new media.

Based on the results that have been obtained and observed in the implementation of this cycle I action, the researchers made improvements in cycle II learning. The efforts made in the improvement are the arrangement and preparation in starting learning.

\subsubsection{Cycle II}

Cycle II research action was conducted on February 20, 2020, with the theme "Work" and the weekly sub-theme "Doctor", which was carried out for 2 × 30 minutes. This implementation was conducted through four stages: planning, implementation, observation, and reflection stages. 
1) Planning

At this stage, the researcher takes a syllabus to direct student learning according to the education curriculum unit, then compiles a Daily Learning Action Plan (DLAP) according to the theme that will be given. In the preparation of DLAP, there is a collaboration between researchers, classroom teachers, and principals so that the teaching and learning process can be carried out properly.

2) Implementation or action

a. Initial Activities

At this stage, the teacher/researcher enters the classroom and organizes the tools used in the learning process, such as preparing a laptop, projector, etc. then begins with greeting students followed by morning worship and pray before studying and singing the song according to the theme that will be taught today, then talk about the teaching and learning activities carried out on the previous day by asking the children a question "who still remembers the song that the teacher taught before, which is the song about various kinds of work? does anyone still remember?", then the song was sung together, and teacher continues with the question "What did we learn yesterday? Come on, who still remember?". The Children's answers could be the basis for the researcher to know how children's knowledge in remembering the material has been taught.

\section{b. Core Activities}

\section{Step I: Delivering today's learning activities}

In this step, the teacher tells students about today's learning which is about the work of doctors and the medical tools, using PowerPoint audio-visual media

\section{Step II: Preparing students}

After explaining today's learning, the researcher assisted by the classroom teacher in arranging the student's seat in a group. This aims to provide a comfortable learning atmosphere for children.

\section{Step III: Start learning activities}

After preparing the students, the researcher started the learning activity that displayed an image in a PowerPoint slide and video songs about doctors' work and doctors' medical equipment.

\section{Step IV: Checking the child's understanding of the material presented}

After the researcher displayed pictures and videos of a doctor's work and the tools a doctor uses, researchers reviewed a doctor's work and what tools a doctor uses in carrying out the work. In this activity researcher give the child the opportunity to think according to their expectations, then the researcher asks questions about the material presented, such as "what are the duties of a doctor? what are the tools used by the doctor? Where does the doctor work?" Here, the children begin to develop their cognitive by thinking what they have heard and seen, then the children start guessing and begin to find answers according to their thoughts, and some children start telling stories about doctor's work according to what they have experienced in daily life. 


\section{c. Closing}

At this stage, the teacher/researcher gives an evaluation in the form of an assessment sheet to know the extent of the child's cognitive development in understanding today's learning, then the teacher gives appreciation and motivation to the child. In the end, the teacher invites the child to pray together after learning and then closes the learning process.

\section{3) Observation}

In this cycle II of observation, the researcher observed the child's behavior and looked at the child's ability to receive and understand the material conveyed. Researchers observed the child's response to the material that had been delivered. This can be seen from the assignments given to the child. Based on observations in this cycle II, the researcher prepared an assessment sheet to show the learning process's assessment results. The researcher conducts an assessment of class mastery, whether it has been maximal or needs improvement for further learning.

Table 2. Children's Learning Outcomes in Cycle II I
\begin{tabular}{|c|c|c|c|c|c|c|}
\hline \multirow{2}{*}{ No. } & Child & \multicolumn{2}{|c|}{ Assessment Aspect } & Score \\
\hline & Name & BB & MB & BSH & BSB & \\
\hline 1. & AX & & & & $\checkmark$ & 4 \\
\hline 2. & CJ & & $\checkmark$ & & & 2 \\
\hline 3. & CR & & & & $\checkmark$ & 4 \\
\hline 4. & ES & & & & $\checkmark$ & 4 \\
\hline 5. & FT & & & & $\checkmark$ & 4 \\
\hline 6. & GL & & & $\checkmark$ & & 3 \\
\hline 7. & HH & & & $\checkmark$ & & 3 \\
\hline 8. & JM & & & & $\checkmark$ & 4 \\
\hline 9. & JR & & & $\checkmark$ & & 3 \\
\hline 10. & KK & & & & $\checkmark$ & 4 \\
\hline 11. & LP & & & & $\checkmark$ & 4 \\
\hline 12. & MT & & & & $\checkmark$ & 4 \\
\hline 13. & QS & & & $\checkmark$ & & 3 \\
\hline 14. & SM & & & & $\checkmark$ & 4 \\
\hline 15. & SB & & & $\checkmark$ & & 3 \\
\hline 16. & TR & & $\checkmark$ & & & 2 \\
\hline 17. & YK & & & $\checkmark$ & 4 \\
\hline
\end{tabular}

From the above results, it can be seen that the achievements are:

$$
\begin{aligned}
\mathrm{LC} & =\frac{T}{T t} \times 100 \% \\
& =\frac{59}{68} \times 100 \% \\
& =86,76 \%
\end{aligned}
$$

Based on the table above, it can be explained that none of the 17 children who participated in learning activities in cycle II have a score (1) or in the sense that there were no Undeveloped children (BB) in cognitive aspects. While in the Assessment of Started Development (MB), two children scored (2). This is because in cycle I, the children do not have 
the ability in the cognitive development aspect, that the child has not been able to do the assigned task correctly and appropriately as taught in cycle I, but in this cycle II, the child has been able to do the task given with the help of the teacher or researcher. Both children are categorized as starting to develop because they have special needs, so there is a delay in developmental aspects. Besides, five children classified as Developed as Expected (BSH) or got a score (3). The children have been able to work and answer the question given. Although there are still doubts when answering questions, the children can answer correctly when teachers give the assignment. There are ten children classified as Very Well Developed (BSB) or got score (4). The children have answered questions or do the teacher's assignments correctly and adequately but still, need guidance and direction from the teacher. Here are the assessment criteria: Children who got scores 3 and 4 are children who can be classified succeeded in showing progress in developing cognitive aspects of children aged 4-5 years using PowerPoint audio-visual media. So, because in this cycle II, 15 children succeeded in improving cognitive using PowerPoint audio-visual media, it means that this research does not need to be continued in the next cycle, because it has achieved the success indicators that have been determined, although there are still two children who are just starting to develop. The two children are categorized as starting to develop because both have mental retardation or so-called special needs, so there is a delay in development.

\subsection{Discussion}

The data analysis in this study occurred interactively both before, during, and after the study. Before the study was conducted, researchers had done an analysis that determined the formulation of the problem that appeared. Then the analysis was also carried out when collecting data of the child's initial abilities. Analysis before this study aims to determine the extent of the problem and the child's ability so that the appropriate research actions can be carried out.

Based on the observations about the implementation of learning and the impact of the stimulus that has been given to children, it shows that the most dominating problem is related to children's cognitive problems.

Evaluation of learning outcomes is carried out at the end of the cycle I and cycle II. Evaluation of results is used to assess student's ability in understanding the materials being taught using PowerPoint audio-visual media.

In this activity, students are asked to work on the question according to the material that has been studied before. The evaluation used is the evaluation of the results and the evaluation of the process.

Based on the results obtained by students through the test, it can be concluded that the study of "Cognitive Development for Preschooler 4-5 Year Olds by Using PowerPoint AudioVisual Media on ECE Students" has been successfully carried out. Thus, this cycle II research is declared successful and does not need to be continued in the next cycle.

\section{Conclusion}

Based on the results of research conducted in ECE in North Tomohon Sub-District, before using PowerPoint audio-visual media, ECE in Tomohon Sub-District still had difficulties in doing the assignments and answering questions from teachers because the children's cognitive was not stimulated well. The use of PowerPoint audio-visual media can improve children's cognitive aspect because the learning activities are designed to be attractive, fun, and not boring 
for ECE students in the North Tomohon Sub-District. By using PowerPoint audio-visual learning media, the children's cognitive can be stimulated well.

\section{Acknowledgment}

The authors are grateful to express gratitude to those who have had the pleasure to cooperate during this study.

\section{Declaration of Conflicting Interests}

The authors have declared no potential conflicts of interest concerning the study, authorship, and/or publication of this article.

\section{References}

Iskandar, D., \& Narsim. (2015). Penelitian Tindakan Kelas dan Publikasinya Untuk Kenaikan Pangkat dan Golongan Guru E Pedoman Penulisan PTK bagi Mahasiswa. Cilacap. Indonesia: Ihya Media.

Republik Indonesia. (2003). Undang-Undang Republik Indonesia Nomor 20 Tahun 2003 Tentang Sistem Pendidikan Nasional. Lembaran Negara Republik Indonesia Tahun 2003 Nomor 78. Jakarta: Sekretaris Negara Republik Indonesia.

Sadiman, A. S. (2010). Media Pendidikan Pengertian Pengembangan dan Pemanfaatannya. Jakarta, Indonesia: Rajawali Pers.

Sanaky, H. A. (2011). Media Pembelajaran: Buku Pegangan Wajib Guru dan Dosen. Yogyakarta, Indonesia: Kaukaba Dipantara.

Sudarna. (2014). Pendidikan Anak Usia Dini. Yogyakarta, Indonesia: Distribusi Nasional.

Sugiyono. (2013). Metode Penelitian Pendidikan Pendekatan Kuantitatif, Kualitatif, dan RED. Bandung, Indonesia: Alfabeta.

Trianto. (2011). Mendesain Model Pembelajaran Inovatif Progresif. (4 ed.). Jakarta, Indonesia: Kencana.

Wina, S. (2011). Penelitian Tindakan Kelas. Jakarta, Indonesia: Kencana.

\section{About the Author}

Ni Dewi Eka Suwaryaningrat obtained her Master's degree in Education Management from Universitas Negeri Manado, Indonesia, in 2012. The author is an Assistant Professor at the Department of Teacher Education for Early Childhood Education, Faculty of Science Education, Universitas Negeri Manado, Indonesia.

E-Mail: nidewiekha@unima.ac.id 